\title{
Comparative Study of Efficacy of Dhattura Beeja Ointment \& Sarshapa Ointment in the Management of Vipadika (Cracked heel)
}

\author{
Research Article
}

\begin{abstract}
Raju Meena1, Nilima Wadnerwar2*, Nishigandha Jagtap1
1. PG Scholar, 2. Associate Professor, Department of Agadtantra, Mahatma Gandhi Ayurved College, Hospital \& Research Centre, Salod(H), Datta Meghe Institute of Medical Sciences (DU), Wardha.
\end{abstract}

\begin{abstract}
Background: Vipadika is one of the Vataja Nanatmaja Vikara which is also considered as Kshudra Kustha. The patient suffering with disease feel severe pain and it increases with the progression of disease. Ayurveda described various therapeutic approaches for the management of Vipadika like; Shodhana Chikitsa, Abhyantara Chikitsa and Bahya Chikitsa, etc. To provide a potent topical drug and to solve the cosmetic problem of the heel the study was undertaken. Methodology: A randomized single blinded study was designed to assess efficacy of the topical preparation made from natural drugs for the management of Vipadika. Dhattura beeja ointment and Sarshapa ointment was prepared and standardized. 15 patients were enrolled in each group. Group A received Sarshapa ointment and served as control group and group B received Dhattura beeja ointment. Both the groups were assessed for number of cracks and pain in cracks. Statistical analysis was conducted using student's paired and unpaired t test at $\mathrm{p}<0.05$ as level of significance. Result: Dhattura Beeja ointment significantly reduced number of cracks and pain associated with cracks on heel in comparison with Sarshapa ointment without any adverse effect. Conclusion: Dhattura beeja ointment is efficacious and can be used safely in the management of Vipadika.
\end{abstract}

Key Words: Dhattura Beeja, Sarshapa, Vipadika, Kshudra Kustha.

\section{Introduction}

Ayurveda has described various types of diseases related to skin and Kustha Roga is one of them. Kshudra Kustha is one of the types of Kustha Roga. Vipadika is included in the Kshudra Kustha, which is also considered as one of the types of Vataja Nanatmaja

Vikaras. (1,2) Vipadika is defined with manifestations as Pani Sphutana (Cracks in palm), Pada Sphutana (Cracks in feet), Teevra Vedana (Severe pain), Kandu (Itching), Daha (Burning), Ruja (Pain), Raga (Redness) and Pidaka (Rashes). It is treated with Shodhana (Virechana, Rakta Mokshana and Vamana), Abhyantara chikitsa (Tundi Ghrita, Triphaladi Ghrita, Mahakalanala Rasa, Vijaya Parpati \& Rasa Taleshvara Rasa) and Bahya Chikitsa (Dhattura Beeja Taila, Kusthadya Taila, Vipadikahara Ghrita Taila, Tandula Lepa, Lepa of Khadira and Shatapaki ghrita). (3-7)

Heel is an integral and important part of foot. Nobody can deny the importance of heel as it is undertaking various physical activities. It is difficult to imagine a person running or walking with injured heels. There are certain diseases associated with foot in

* Corresponding Author:

Nilima Wadnerwar

Associate Professor, Department of Agadtantra,

Mahatma Gandhi Ayurved College, Hospital \&

Research Centre, Salod(H), Datta Meghe Institute of

Medical Sciences (DU), Wardha.

Email Id: dr.nilima wadnerwar@rediffmail.com general and heel in particular. Such abnormality may lead to temporary or permanent dysfunction of heel. Cracks in heel seem like a minor breech in the anatomy of the heel but as it progresses, it can produce severe pain and sometimes bleeding. Heel has cosmetic importance as it can be a social stigma especially in females. The pain present in Vipadika is so intense that it severely affects the quality of life. There are some remedies available in the market in cream form which only smoothens the heels. Cracks are not completely healed and it has reoccurrence. In Ayurveda, internal as well as external treatment is described for Vipadika. But patients want quick relief with less medicine. Hence, Dhattura beeja ointment mentioned in Chakradatta in Kushtha Chikitsa has been selected as external application to study the safety and efficacy in comparison with plain Sarshapa ointment.

\section{Materials and Methods}

Approval from Institutional Ethics Committee was obtained before conducting the study (Reference no. DMIMS (DU)/IEC/2019/7953). The raw drugs were collected, identified and authenticated from department of Dravyaguna, Mahatma Gandhi Ayurved College, Hospital and Research Centre, Salod (H), Wardha.

\section{Collection of Material}

$500 \mathrm{gm}$ seeds of Dhattura (Datura metel Linn) were collected from Shaila Pharma, Nagpur and 10Kgs of Mankanda (Alocacia indica Lour) was procured from Government Ayurved College, Gwalior. 4000ml 
Sarshapa taila (Mustard oil) and $2 \mathrm{kgs}$ of wax were procured from local market. The study was conducted in two phases: I) Pharmaceutical study and II) Clinical study. The pharmaceutical study included shodhana (purification) of Dhattura, prepration of Dhattura Beeja ointment and Sarshapa ointment and their standardization.

\section{Method of Preparation of Dhattura Beeja Ointment} (8-11)

\section{Shodhana (Purification) of Dhattura Beeja}

Dried Dhattura seeds were collected \& physical impurities were removed. Seeds were tied in Pottali with clean cloth. Dolayantra filled with cow's milk was used for Swedana purpose of seeds for three hrs. After Shodhana, Dhattura seeds were taken out from the Pottali and washed under tap water. Seeds were dried \& kept in airtight container.

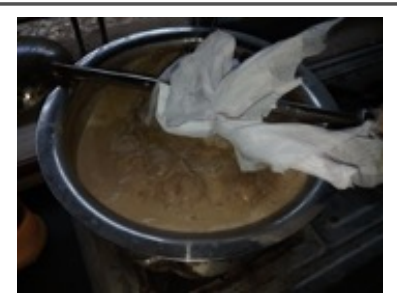

Fig. 1 Dhattura beeja Shodhan

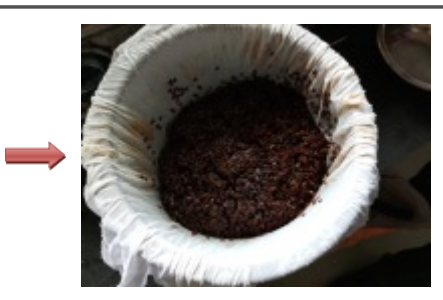

Fig.2 After Shodhana

\section{Preparation of Maankanda Ksharajala}

Dried Maankanda was burnt as per standard procedure to prepare Kshara (Alkaline powder) and ash was kept in water for overnight. Next day clear water was collected and filtered seven times through a clean cotton cloth. The water obtained after filtration is considered as Maankanda Ksharajala.

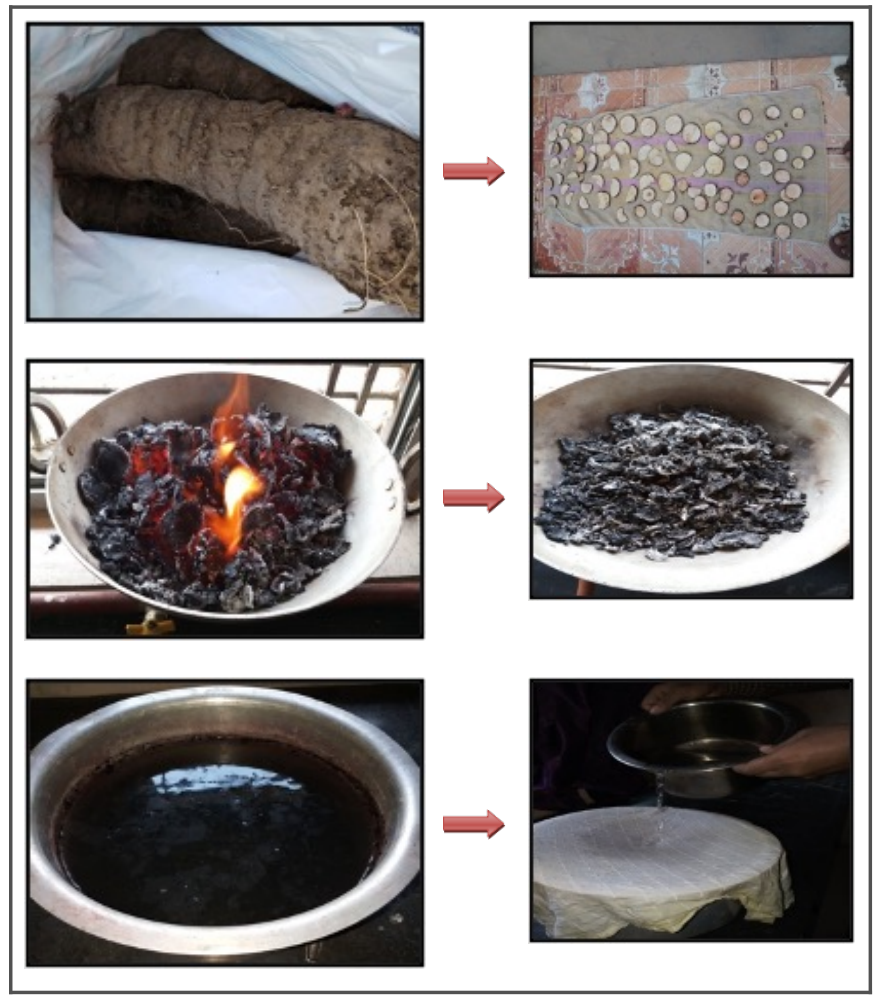

Fig. 3 Maankanda kshariya jala

\section{Preparation of Dattura Beeja Taila}

2 litres of Sarshapa taila was poured in a vessel kept on fire and it was boiled until it became free from froth. 500gms of Dhattura Beeja Kalka was mixed in it. Maanakanda Ksharajala was added \& boiled on moderate heat until all water content gets evaporated. After observing the Taila Siddha Lakshana, it was allowed to cool. Finally, it was filtered with clean cotton cloth.

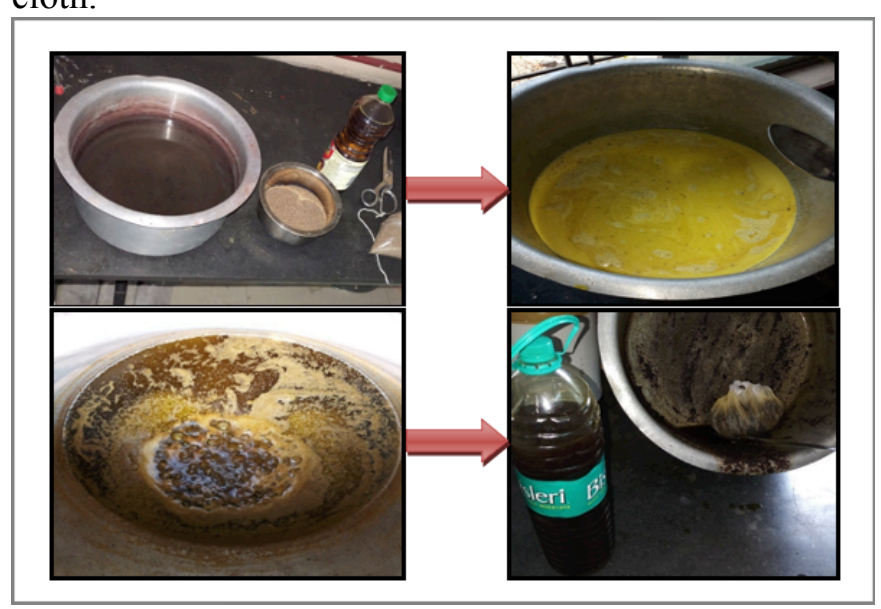

Fig. 4 Preparation of Dhattura beeja taila

\section{Preparation of Dattura Beeja Ointment}

$500 \mathrm{gm}$ wax was heated and liquefied wax was mixed with Dhattura Beeja Taila and stirred to make it homogenous mixture, finally semisolid ointment preparation was obtained with uniform consistency. The dose form was modified from oil to ointment for the convenience, better and quick absorption.

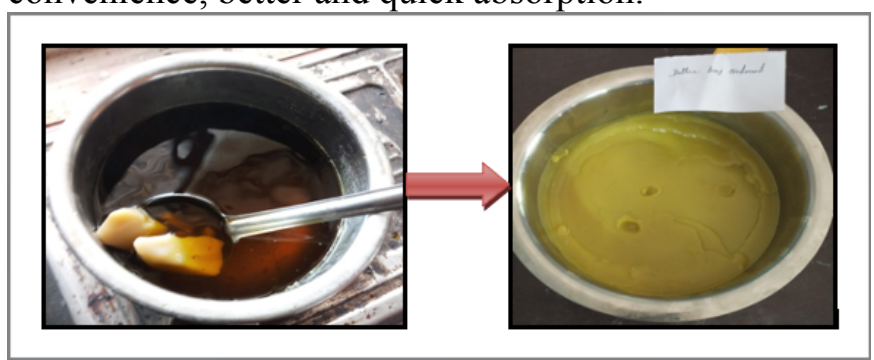

Fig. 5 Preparation of Dattura beeja ointment

\section{Preparation of Sarshapa Ointment}

Sarshapa Taila $(2000 \mathrm{ml})$ was heated until it became free from froth. 500gm Wax was heated till it gets liquefied. It was then mixed in Sarshapa Taila and stirred up to the formation of homogenous mixture.

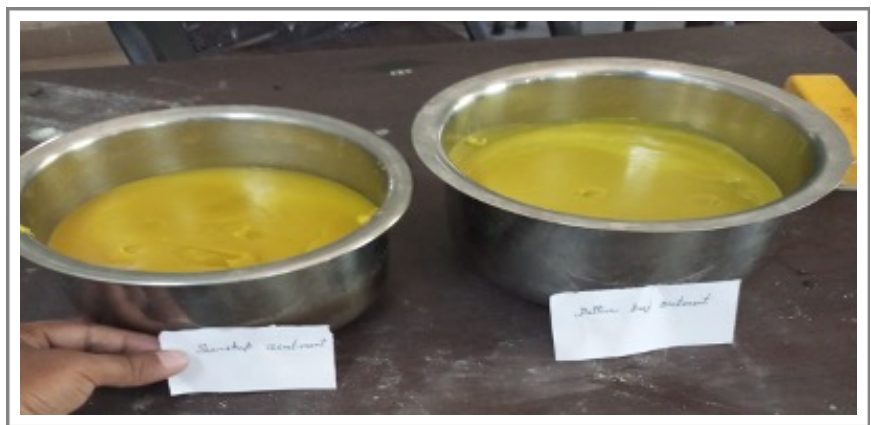

Fig. 6 Final product Sarshapa ointment and Dattura beeja ointment 


\section{Analytical Study}

Both the ointments were subjected to physicochemical analysis and microbial load with the help of microbial limit test.

\section{Clinical Intervention}

A randomized controlled single blinded trial was conducted to compare the efficacy of Dhattura Beeja ointment and Sarshapa ointment. The patients of Vipadika were selected from to Kayachikitsa O.P.D of M.G.A.C.H. and R.C. Salod (H), Wardha. Informed written consent was taken after due consultation with patients. Total 30 patients were participated in this study \& registered patients were distributed in two groups A and group B randomly by lottery method. Fifteen patients were enrolled in each group. Patient of Vipadika having age between 20-60 years with cracks associated with pain (Saruja) were included in the study. Patients under other treatment for Vipadika and having bleeding cracks, open wound, ulcer in feet, diabetic foot and infectious wound on feet were excluded from the study. Group A was considered as control group and treated with Sarshapa ointment whereas group B was considered as trial group and treated with Dhattura Beeja ointment. As Sarshapa oil is one the ingredients in Dhattura beeja ointment, it was used a common ingredient for both groups for comparison.

Number of cracks per foot, number of cracks associated with pain per foot were noted and photographs of the feet in exposure of light in prone position were taken before and after the intervention. Sensitivity test was conducted to observe any rash, itching, redness, burning or ulcer formation. First application was performed under the physician's supervision and for subsequent applications, patients were asked to apply the lepa at home every day for seven consecutive days at bedtime. The patients were advised to apply ointment with an applicator and to retain the ointment overnight and then to wash the feet in the morning with lukewarm water. They were also advised to wash the hands immediately after application and not to touch eyes and other external orifices.

\section{Assessment parameter}

Number of cracks of both the feet was counted and minute fissures were ignored.

Table No 1: Number of Cracks on feet

\begin{tabular}{|l|l|} 
Cracks on feet & Grades \\
\hline No cracks & 1 \\
\hline 1 to 3 cracks & 2 \\
\hline 4 to 6 cracks & 3 \\
\hline More than 6 cracks & 4 \\
\hline
\end{tabular}

Table No.2: Cracks associated with pain

\begin{tabular}{|l|l|} 
Pain in Cracks & Grades \\
\hline No Pain & 1 \\
\hline Pain on digital pressure & 2 \\
\hline Pain while walking & 3 \\
\hline Pains more / constant pain & 4
\end{tabular}

\section{Statistical analysis}

Statistical analysis was done by using descriptive and inferential statistics using student's paired and unpaired ' $\mathrm{t}$ ' test, and software used in the analysis were SPSS 22.0 version and Graph Pad Prism 6.0 version and $\mathrm{p}<0.05$ is considered as level of significance.

\section{Observations and Results}

Table No 3: Organoleptic and physicochemical analysis

\begin{tabular}{|c|l|c|c|}
\hline \multirow{2}{*}{ SN } & & Test parameter & Test Result \\
\hline 1 & Color & Yellow & Dhattura Beeja ointment \\
\hline 2 & Odor & Pungent & Yellow \\
\hline 3 & Ph & 6.18 & Pungent \\
\hline 4 & Fatty matter & $59 \%$ & 7.86 \\
\hline 5 & Loss on drying at $105^{\circ} \mathrm{C}$ & $2.9 \%$ & $57 \%$ \\
\hline
\end{tabular}

Table No 4: Microbial Load/ Specifications

\begin{tabular}{|c|c|c|c|c|}
\hline \multirow{2}{*}{ SN } & \multirow{2}{*}{ Test parameter } & \multicolumn{2}{|c|}{ Test Result } & \multirow{2}{*}{ API Value } \\
\hline & & Sarshapa ointment & Dhattura Beeja ointment & \\
\hline 1 & Enterobacteria & Absent & Absent & $10^{3} / \mathrm{gm}$ \\
\hline 2 & Total fungus count & Absent & Absent & Maximum 103/gm \\
\hline 3 & $\mathrm{E}-$ coli & Absent & Absent & Maximum $10 / \mathrm{gm}$ \\
\hline 4 & Salmonella spp & Absent & Absent & None \\
\hline 5 & Staphylococcus aureus & Absent & Absent & Absent \\
\hline 6 & Pseudomonas aueruginosa & Absent & Absent & Absent \\
\hline 7 & Total viable count & Absent & Absent & Maximum $10^{5} / \mathrm{gm}$ \\
\hline
\end{tabular}

Table No 5: Categorization of patients according to Sex

\begin{tabular}{|c|c|c|c|c|c|c|}
\hline \multirow{2}{*}{ Sex } & Group A Patients & \multicolumn{2}{|c|}{ Group B Patients } & Total Patients & Total Patients in \% \\
\hline Male & No. & $\mathbf{\%}$ & No. & \% & 10 & 33.3 \\
\hline Female & 2 & 13.33 & 8 & 53.33 & 20 & 66.7 \\
\hline
\end{tabular}


Table No. 6: Categorization of patients according to their age group.

\begin{tabular}{|c|c|c|c|c|c|c|}
\hline \multirow{2}{*}{ Range of Age } & \multicolumn{4}{|c|}{ No. of patients } & \multicolumn{2}{c|}{ Total Patients } \\
\hline & Group-A & $\mathbf{\%}$ & Group-B & $\mathbf{\%}$ & Number & Percentage \\
\hline $19-28$ & 6 & 40 & 6 & 40 & 12 & 40 \\
\hline $29-38$ & 6 & 40 & 6 & 40 & 0 & 0 \\
\hline $39-48$ & 0 & 0 & 0 & 0 & 3 & 10 \\
\hline $59-58$ & 1 & 6.67 & 2 & 13.33 & 4 & 13.33 \\
\hline
\end{tabular}

Table No. 7: Categorization of patients according to Agni

\begin{tabular}{|c|c|c|c|c|c|c|}
\hline \multirow{2}{*}{ Agni } & \multicolumn{4}{|c|}{ Number of patients } & \multicolumn{2}{c|}{ Total Patients } \\
\hline Sama & Group-A & \% & Group-B & \% & Number & Percentage \\
\hline Vishama & 1 & 6.66 & 2 & 13.33 & 3 & 10 \\
\hline Manda & 6 & 40 & 5 & 33.33 & 11 & 36.66 \\
\hline Tikshna & 6 & 40 & 6 & 40 & 12 & 40 \\
\hline
\end{tabular}

Table No. 8: Categorization of patients according to Koshtha

\begin{tabular}{|c|c|c|c|c|c|c|}
\hline \multirow{2}{*}{ Kostha } & \multicolumn{4}{|c|}{ No. of patients } & \multicolumn{2}{c|}{ Total Patients } \\
\hline Mrudu & Group-A & \% & Group-B & \% & Number & Percentage \\
\hline Maddhyam & 3 & 20.00 & 5 & 33.33 & 8 & 26.66 \\
\hline Krura & 5 & 33.33 & 3 & 2.000 & 8 & 26.66 \\
\hline
\end{tabular}

Table No. 9: Assessment of Number of Cracks in group A with Sarshapa Ointment

\begin{tabular}{|c|c|c|c|c|c|c|c|c|}
\hline Group A & Mean & $\mathbf{n}$ & SD & SE & Mean difference & \% Improvement & t value & p value \\
\hline BT & 2.86 & \multirow{2}{*}{15} & 0.83 & 0.21 & 1.4 & 45 & 5.95 & $<0.05^{*}$ \\
\hline AT & 1.46 & & 0.51 & 0.13 & & & \\
\hline
\end{tabular}

Table No 10: Assessment of Pain in cracks in group A with Sarshapa Ointment

\begin{tabular}{|c|c|c|c|c|c|c|c|c|}
\hline Group A & Mean & $\mathbf{n}$ & SD & SE & Mean difference & \% Improvement & t value & p value \\
\hline BT & 2.8 & 15 & 0.94 & 0.24 & 1.4 & 46.11 & 6.5479 & $<0.05^{*}$ \\
\hline AT & 1.4 & & 0.50 & 0.13 & & &
\end{tabular}

Table No 11: Assessment of Number of cracks in group B with Dhattura beeja Ointment

\begin{tabular}{|l|l|l|l|l|l|l|l|l|} 
Number of cracks & Mean & n & SD & SE & Mean Difference & $\%$ Improvement & t value & $p$ value
\end{tabular}

\begin{tabular}{|l|l|l|l|l|l|l|l|l|}
\hline BT & 2.66 & 15 & 0.8165 & 0.2108 & 1.93 & 61.42 & 9.5 & $<0.05^{*}$ \\
\hline AT & 0.73 & & 0.7213 & 0.1862 & & & \\
\hline
\end{tabular}

Table No 12: Assessment of Pain in cracks in group B with Dhattura beeja Ointment

\begin{tabular}{|c|c|c|c|c|c|c|c|c|}
\hline Pain in cracks & Mean & $\mathbf{n}$ & SD & SE & Mean Difference & \% Improvement & t value & p value \\
\hline BT & 2.53 & 15 & 0.91 & 0.23 & 1.73 & 60 & 8.64 & $<0.05^{*}$ \\
\hline AT & 0.8 & & 0.80 & 0.20 & & &
\end{tabular}

Table No. 13: Comparison of both groups for number of cracks

\begin{tabular}{|c|c|c|c|c|c|c|}
\hline Group & $\mathbf{n}$ & Mean & Standard Deviation & Standard Error of Mean & t-value & P-value \\
\hline A-Sarshapa ointment & 15 & 1.46 & 0.5164 & 0.13333 & 1.31 & $<0.05^{*}$ \\
\hline B-Dhattura beeja ointment & 15 & 0.73 & 0.59362 & 0.15327 & & \\
\hline
\end{tabular}

Table No.14: Comparison of both groups for pain in cracks

\begin{tabular}{|c|c|c|c|c|c|c|}
\hline Group & $\mathbf{N}$ & Mean & Standard Deviation & Standard Error of Mean & t-value & P-value \\
\hline A-Sarshapa ointment & 15 & 1.4 & 0.50709 & 0.13093 & 2.04 & $<0.05^{*}$ \\
\hline B-Dhattura beeja ointment & 15 & 0.8 & 0.56061 & 0.14475 & & \\
\hline
\end{tabular}




\section{Overall effect of Sarshapa ointment}

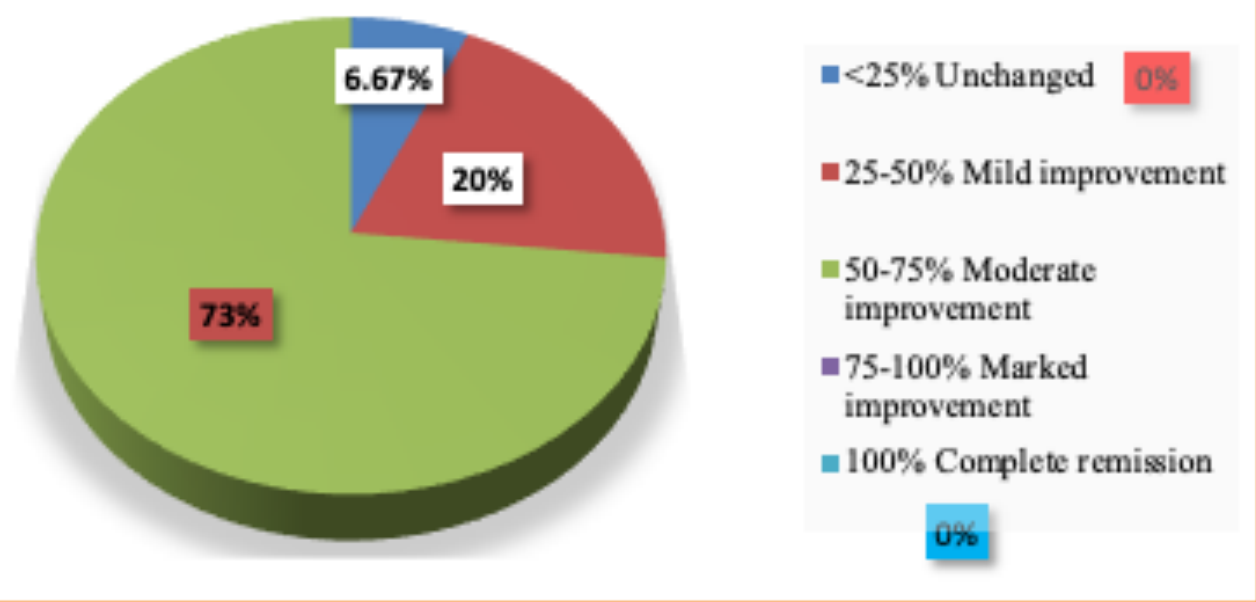

Graph 1: Overall effect of Sarshapa ointment in the management of disease

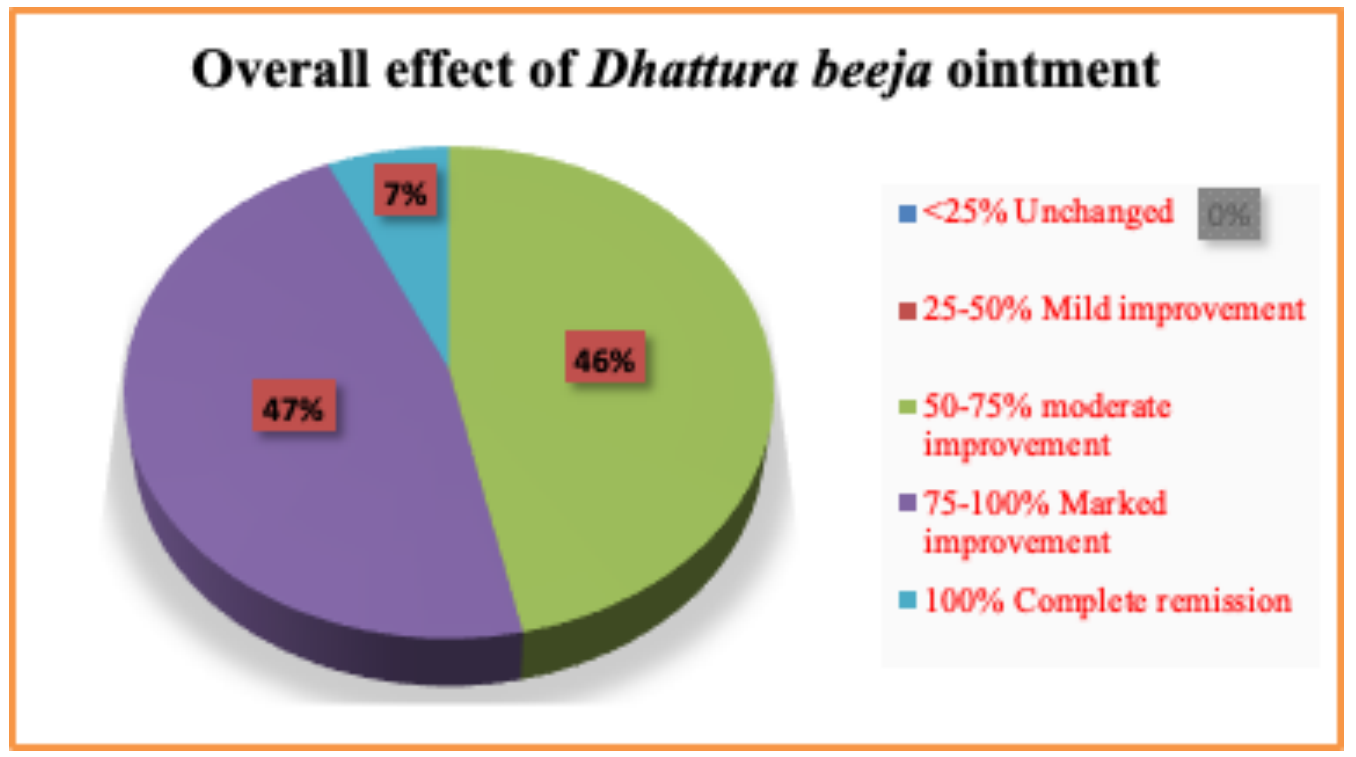

Graph 2: Overall effect of Dhattura beeja ointment in the management of disease

\section{Discussion}

Leaves, roots, fruit and seeds of Dhattura (Datura metel Linn) belonging to solanaceae family are used in treatment for various purposes, though they are toxic. The parts are known to reduce pain and inflammation. They are used in Jwara (fever), shwasa (athma), kasa (cough), amlapitta (acidity), parinamshool (abdominal pain), pittaashmari (gall stones), shotha (inflammation), dandruff etc. Sharangdhara, Bhava Mishra and Chakradatta have mentioned about Dhattura beeja taila in the treatment of Vipadika.

After physicochemical analysis, it was observed that the parameters of both ointments are within normal limits and there was no bacterial contamination in the study drugs. In the present study, most of the registered patients belong from Manda Agni while Sama Agni was observed only in $10 \%$ registered patients. It was observed that maximum patients belong from Krura Kostha as compared to Mrudu and Maddhyam Kostha.

The study was carried out to measure effect of Dhattura Beeja ointment in the management of
Vipadika in comparison with Sarshapa ointment. The mean score of number of cracks was 2.86 before treatment which reduced to 1.46 after treatment with Sarshapa ointment which is statistically significant $(p<0.05)$ and the relief is $45 \%$. The mean score of pain in cracks was 2.8 before treatment which reduced to 1.8 after treatment with Sarshapa ointment which is statistically significant $(p<0.05)$ and the relief is $46.11 \%$. The mean score of number of cracks was 2.66 before treatment which reduced to 0.73 after treatment with Dhattura Beeja ointment which is statistically significant $(\mathrm{p}<0.05)$ and the relief is $61.42 \%$.

The mean score of pain in cracks was 2.53 before treatment which reduced to 0.8 after treatment with Dhattura Beeja ointment which is statistically significant $(\mathrm{p}<0.05)$ and the relief is $60 \%$. When both the groups were compared for the effect of drug on number of cracks and pain in cracks, it was found that pain and number of cracks and pain reduced significantly in group B with Dhattura Beeja ointment in comparison with Group A (Sarshapa ointment). 
Overall Effect of Sarshapa Ointment

It was observed that after treatment with Sarshapa ointment, $73 \%$ patient received moderate improvement, $20 \%$ patients received mild improvement while $6.67 \%$ patients remain unchanged. Marked improvement and complete remission were not observed (Graph No. 1).

\section{Overall Effect of Dattura beeja Ointment}

It was observed that after treatment with Dattura beeja ointment, $7 \%$ patients has complete remission, $47 \%$ of patients received marked improvement while $46 \%$ received moderate improvement (Graph No. 2).

The findings of study suggested that Dhattura beeja ointment offers more beneficial effects in reducing pain and number of cracks on heel in comparison with Sarshapa ointment. The Dhattura beeja ointment contains Dhattura and Mankanda, these components of formulations offers healing and soothing effects thus provide better relief in the management of pain and cracks on heel.

Apart from this, no patient was found sensitive to Dhattura Beeja ointment and any local adverse effects like rash, redness, itching burning etc was not observed during the study. Dhattura beeja ointment is found to be safe for local application in comparison with other upavisha like Gunja (Abrus preatorius Linn). $(12,13)$

\section{Probable mode of action of Dhattura Beeja ointment}

The Snigdha guna of Mankanda might have helped to control Vata thus prevent Rukshata and Kharasparsha in Vipadika. The lubrication helps for moistening and softening of skin. The Dhattura Beeja ointment subsided Kandu by virtue of Vishagna, Kaphagna and Kandughna properties of Dhattura. Krimigna property of Dhattura \& Mankanda also helps to reduce Kandu. Vedana might have subsided by the Vedanasthapaka action of Mankanda while Srava might have been cured by the Sthambaka action of Mankanda. Kashaya rasa and Sandhaneeya properties of Dhattura also pacify Srava. Daha might have subsided by the Pitta Shamaka properties of Mankanda while Kustaghna \& Kandughna properties of Dhattura \& Mankanda along with Sneha dravyas help to relief symptoms of Vipadika.

\section{Conclusion}

Study concluded that prevalence of Vipadika is irrespective of age, sex and prakruti but predominantly seen in Madhyama vaya and patients with Vatakapha prakriti. Kala, Desha, Vihara plays an important role in occurrence of Vipadika. The topical herbal formulations can offer beneficial effects in the management of the disease. Dhattura beeja ointment is one of such types of herbal topical formulation that offers beneficial effects in the management of Vipadika. Dhattura beeja ointment can relief symptoms like; number of cracks \& pain associated with Vipadika. Study compared effect of Dhattura beeja ointment with Sarshapa ointment in the management of Vipadika and it may be concluded that Dhattura beeja ointment can be used safely in the management of Vipadika as it offers better results than Sarshapa ointment.

\section{Acknowledgement}

Datta Meghe Institute of Medical Sciences (DU), Wardha, Maharashtra, India.

\section{References}

1. Pandeya G. The Charaka Samhita of Agnivesha. Reprint. Varanasi; Chaukhambha Samskrit Sansthana, 2006. 202p.

2. Pandeya G. The Charaka Samhita of Agnivesha. $5^{\text {th }}$ edition. Varanasi; Chaukhambha Sanskrit Sansthana; 1997. 269p.

3. Dwivedi R. Chakradatta of Chakrapanidatta. $3{ }^{\text {rd }}$ edition. Varanasi; Chaukhambha Sanskrit Sansthana. 1997. 282p.

4. Pandeya G. The Charaka Samhita of Agnivesha. Reprint. Varanasi; Chaukhambha Samskrit Sansthana, 2006. 215p, 217p.

5. Dwivedi R. Chakradatta of Chakrapanidatta. $3^{\text {rd }}$ edition. Varanasi; Chaukhambha Sanskrit Sansthana. 1997.

6. Pandeya G, The Charaka Samhita of Agnivesha. Reprint. Varanasi; Chaukhambha Samskrit Sansthana, 2006. 218p.

7. Kunte A M. Navare K R S Annotated. Astanga Hridaya of Vagbhata, Reprint. Varanasi; Chaukhambha Surabharati Prakashan. 2002. 712p.

8. Shastri K. Rashtarangini. Delhi; Motilal Banarasidas Publication. 2000. 711p.

9. Murthy S. Sharangdhara Samhita of Sharangdhara. Varanasi; Chaukhambha Orientalia. 156-157p.

10.Dwivedi R. Chakradatta of Chakrapanidatta. $3^{\text {rd }}$ edition. Varanasi; Chaukhambha Sanskrit Sansthana. 1997. 282p, 394p.

11. Shastri K. Rashtarangini. Delhi; Motilal Banarasidas Publication. 2000. 17p.

12. Wadnerwar N. N, Prasad K. S. R, Deogade M, Kadu A. Comparative study of efficacy of Gunja Beeja lepa and Shunthi Churna lepa in Inflammatory Conditions of Arthritis - A Randomized Controlled Single Blinded Clinical Study. International Journal of Ayurvedic Medicine. 2020; 11(2); 200-204.

13. Wadnerwar N. N, Prasad K. S. R, Efficacy and Adverse Effects of Gunja Beej Lepa - A case series. Journal of Indian System of Medicine. 2015; 3(2); 91-95. 


\section{Images of patients}
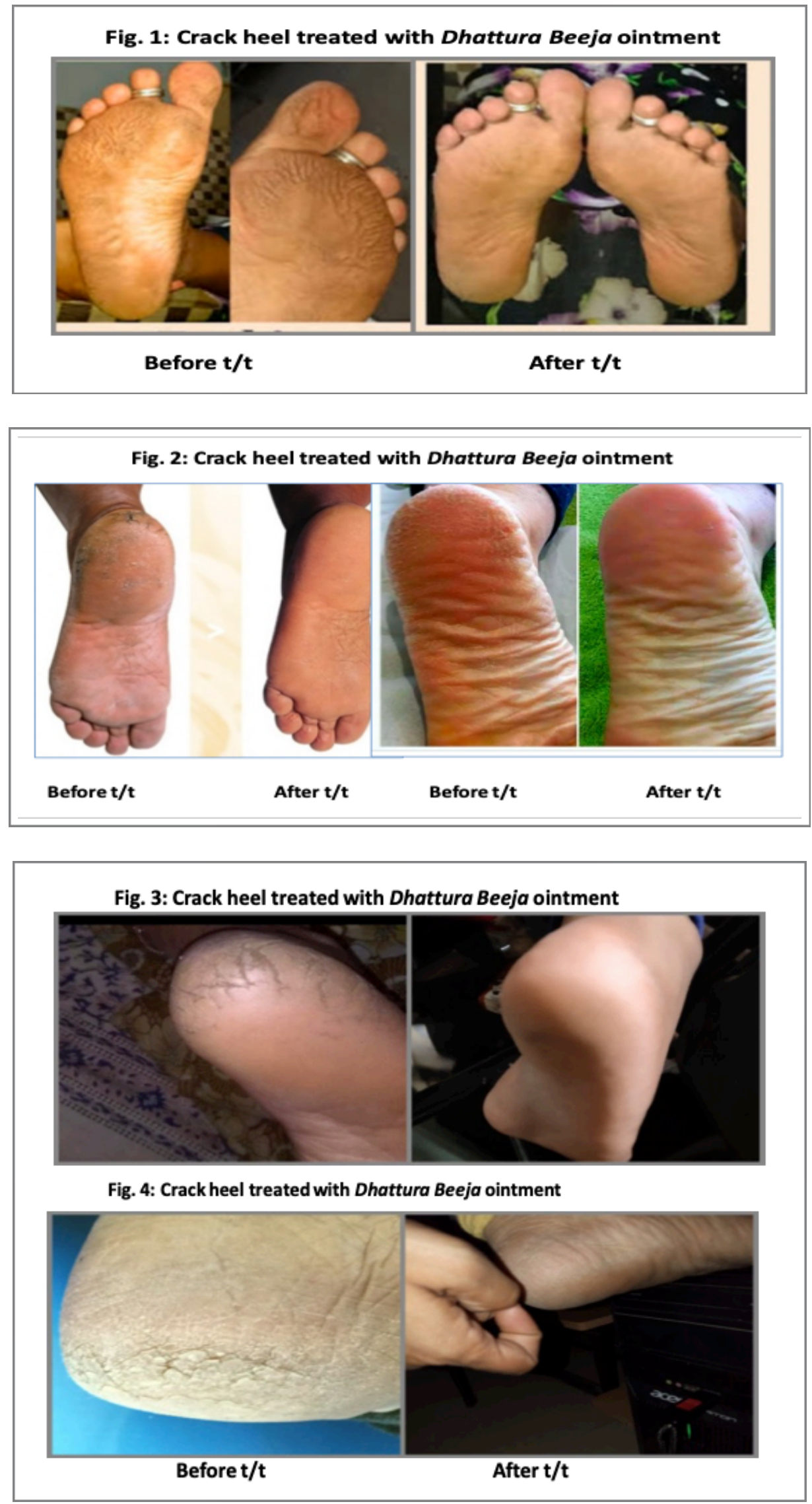

$* * * * *$ 